\title{
Soft Tissue Sarcoma of the Abdomen and Thoracic Visceral Organs cM0 TNM Finding v8
}

National Cancer Institute

\section{Source}

National Cancer Institute. Soft Tissue Sarcoma of the Abdomen and Thoracic Visceral

Organs CMO TNM Finding v8. NCI Thesaurus. Code C136727.

Soft tissue sarcoma of the abdomen and thoracic visceral organs without distant

metastases. (from AJCC 8th Ed.) 